\title{
Antidumping Petition, Foreign Direct Investment, and Strategic Exports
}

\author{
Yasukazu Ichino \\ Faculty of Economics, Konan University \\ 8-9-1 Okamoto, Higashinada-ku Kobe 658-8501, Japan \\ Tel: 81-78-435-2596 E-mail: yichino@center.konan-u.ac.jp
}

Received: December 4, 2012

Accepted: January 14, 2013

Online Published: March 7, 2013

doi:10.5430/rwe.v4n1p22

URL: http://dx.doi.org/10.5430/rwe.v4n1p22

\begin{abstract}
We examine how the protection-seeking effort of an import-competing industry, in the form of an antidumping petition, is affected by the foreign firm's FDI opportunity. In equilibrium, the protection-seeking effort is either blockading, deterring, or accommodating FDI. When FDI is deterred, the protection-seeking effort decreases as the antidumping duty increases, and the foreign firm can benefit from an increase in the duty. Therefore, when the future duty depends on current exports, the foreign firm may increase its exports in order to dampen protection seeking. Namely, antidumping policy can induce more "dumping" when the foreign firm has an FDI opportunity.
\end{abstract}

Keywords: Antidumping petition, Tariff-jumping, Foreign direct investment, Strategic exports, Endogenous protection

\section{Introduction}

When a tariff is imposed by an importing country, foreign exporting firms may want to make foreign direct investment (FDI) in order to avoid the tariff. This argument, called "tariff-jumping", is one of the traditional explanations for FDI. In recent decades, various studies, such as Brander and Spencer (1987), Smith (1987), Motta (1992), Haaland and Wooton (1998) and Belderbos et al. (2004), have elaborated the theory of tariff-jumping FDI in the framework of oligopoly, focusing on how the FDI of foreign firms is related with the supply of protection by the government of an importing country. On the other hand, there is another line of researches studying how the demand for protection is related with FDI. An example is the theory of quid pro quo investment, such as Bhagwati et al. (1987), Wong (1989), and Grossman and Helpman (1996). More recent papers such as Konishi, Saggi, and Weber (1999) and Kayalicaz and Lahiri (2007) consider the effect of FDI on the political contributions of the firms to influence trade policy.

This paper is going to follow the latter line, focusing on how the demand for protection is affected by FDI opportunity of foreign firms. The bottom line of the idea of this paper is the one pointed out by Ellingsen and Warneryd (1999): import-competing firms do not want the maximal level of a tariff when foreign firms can make FDI. In their paper, Ellingsen and Warneryd assume that the government of an importing country is fully captured by the import-competing industry, so that the government sets a tariff to maximize the profit of the industry. In other words, the industry can costlessly demand the level of protection they want. On the other hand, in this paper we explicitly take account of the cost of protection seeking. Specifically, we model that protection seeking takes the form of a petition for antidumping duty. Thus, the main question we ask is as follows: How does FDI opportunity of foreign firms influence the demand for protection by an import-competing industry, when the demand for protection is in the form of an antidumping petition?

In the U.S., when a petition for antidumping duty is filed, investigations are conducted by the International Trade Commission (ITC) and the Department of Commerce (DOC). The ITC determines whether the import-competing industry is materially injured by the imports from foreign countries, while the DOC determines whether there is dumping, and if there is, the size of dumping margin, by observing the prices in the U.S. and in the foreign countries. In the antidumping procedure, there are three important observations that are relevant to our analysis. First, since the duty (or the tariff (Note 1)) is determined by technical calculations conducted by the DOC, an import-competing industry (the one who files a petition) typically has little influence on the determination of the duty when it files a petition. In fact, some empirical studies reported that the size of the duties determined by the DOC is not very much influenced by political pressure, while injury determinations by the ITC are more subjective, and more susceptible to 
political pressure than dumping determinations by the DOC. (Note 2) Second, the DOC's existence-of-dumping test is easier to pass than the ITC's injury test. Finger and Murry (1993) reported that only $10 \%$ of the petitions have reached negative determination of the existence of dumping, while $49 \%$ has resulted in negative determination of material injury. Thus, whether the duty is imposed or not largely depends on injury determinations by the ITC. Third, a typical antidumping investigation takes 280 to 420 days to reach final determination.

From these three observations, the following three crucial assumptions are made in the paper. First, the size of the duty is dependent on the quantity exported by foreign firms in a period before a petition is filed, but independent of the protection-seeking effort made by the import-competing industry. This assumption comes from the fact that the DOC calculates the dumping margin by observing the market outcomes prior to the petition. The more exports mean the more dumping (i.e., the lower price in the importing county), thus the higher the duty. Also, this assumption reflects that the import-competing industry has little political influence on the determination of the duty when it files a petition.

The second assumption is that the import-competing industry chooses how much to spend for a petition, and that the spending for a petition affects the probability of duty enforcement. Rationales of this assumption are that whether the duty is imposed or not largely depends on the ITC's injury determination, and that the ITC's injury determination is more susceptible to the political pressure than the DOC's dumping determination. We assume that, the more the import-competing industry spends for a petition, the more convincing it can make the petition, and the more likely the duty will be imposed. In other words, protection-seeking effort of the import-competing industry is directed to increase the probability of protection.

Third, we assume that foreign exporting firms choose to make FDI after the import-competing industry filing an antidumping petition, but before whether the antidumping duty is actually imposed or not is determined. In other words, the foreign firms have an opportunity to make anticipatory tariff-jumping FDI. Rationales that the foreign firms are engaged in anticipatory tariff-jumping FDI are that it may take a quite long time to build subsidiary plants and that the foreign firms may lose profit if they do not have plants when the duty is actually imposed. Also, this assumption is made in order to incorporate the observation that the time length of an antidumping investigation is long enough for the foreign firms to make FDI.

From this setting of the model, we derive several interesting results. The first finding of the paper is that the level of protection-seeking effort is either blockading FDI, deterring FDI, or accommodating FDI, depending on the parameter values. In general, FDI is blockaded (deterred) when the foreign firms' gain from investment is small (large) relative to the cost of investment, and the import-competing industry's gain from protection seeking is small (large) relative to the cost of the protection seeking. A numerical analysis shows that accommodation of FDI occurs only in a very limited range of parameter values. This suggests that the actual anticipatory tariff-jumping FDI may not be observed very often under antidumping protection. This finding is consistent with the empirical study of Blonigen (2002), which found that not many firms subject to the U.S. antidumping duties made tariff-jumping FDI.

The second result of the paper is in terms of comparative statics for the protection-seeking effort. We found that, when deterring FDI is optimal, the protection-seeking effort is decreasing in the tariff. The reason is as follows. An increase in the tariff makes the foreign firm engaged in FDI at the smaller level of protection probability. Knowing this, the import-competing firm, whose profit is decreased when the foreign firm makes FDI, will lower its protection-seeking effort and thus lower the probability of protection, in order to keep the foreign firm from making FDI. An important implication of this finding is that the foreign firm can benefit from an increase in the tariff, through a decrease in the probability of protection. In turn, this implication leads to a strategic behavior of the foreign firm in a period prior to the protection-seeking stage, since the tariff depends on how much the foreign firm exported in a period before the protection-seeking stage.

An idea that the level of protection may depend on the market outcome in a period before protection enforcement is first examined by Bhagwati and Srinivasan (1976), and developed by Fischer (1992) and Reitzes (1993), among others. They derived the results that foreign firms strategically decrease exports in order to lower the level of protection in future. On the other hand, Anderson $(1992,1993)$ pointed out a possibility that foreign firms may strategically increase exports when facing future protection.

Different from these papers, in our model, we show that the strategic response of the foreign firm facing future protection is not uniform. On one hand, when the optimal protection-seeking effort chosen by the import-competing firm is to blockade FDI, the foreign firm strategically decreases its exports in order to lower the tariff. This is a result obtained in most of endogenous protection literature. On the other hand, when the import-competing firm is going to deter FDI, the foreign firm strategically increases its exports in order to discourage protection seeking. This is rather 
a new result. Having an FDI opportunity after the protection seeking of the import-competing firm, the foreign firm can dampen the demand for protection by increasing the future tariff.

Blonigen and Ohno (1998) presented the similar results to ours. They showed that there is an equilibrium in which one firm whose cost of FDI is low strategically increases its current exports and the other firm whose cost of FDI is high strategically decreases its current exports, when they face future protection. Despite the similarity of the results, however, empirical implications are quite different between Blonigen-Ohno's model and ours. The result of Blonigen-Ohno implies that when some firms strategically increase their exports, there must be other firms which decrease their exports, and that the increase in the exports must be followed by actual investment. Contrary, in our model all exporting firms may be engaged in a strategic increase in exports. In addition, our model predicts that the strategic increases in exports may not be followed by actual investment, since it is the existence of investment opportunity, not necessarily actual investment, that affects the protection-seeking effort of the import-competing firm. In our setting, the strategic purpose of the foreign firm to increase its exports is to make the threat of investment more credible.

The rest of the paper is organized as follows. In section 2, we describe the outline of the model. In section 3, the model is solved and the results are presented. Then section 4 gives brief concluding remarks.

\section{Description of the Model}

We consider a simple international Cournot duopoly. There are two firms, one in the home country and the other in the foreign country. We call them the home firm and the foreign firm respectively. It is assumed that the market in the foreign country is completely protected, thus the competition between the home firm and the foreign firm takes place only in the home country.

The inverse demand function in the home country is given by $p\left(q_{h}+q_{f}\right)$, with $p^{\prime}<0$. The variable $q_{h}$ denotes the quantity sold by the home firm and $q_{f}$ denotes the quantity sold by the foreign firm. If the foreign firm does not invest in the home country, $q_{f}$ is provided only from exports. If the foreign firm makes FDI, then it can produce at its subsidiary in the home country, so $q_{f}$ can be provided from the subsidiary as well as from exports. The foreign firm's exports are subject to the per unit tariff, $t$, if the protection is imposed in the home country, while the subsidiary production is not subject to the tariff.

For analytical simplicity, we assume that the firms have constant marginal cost of production. Let $c_{h}$ denote the marginal cost of the home firm, $c_{f}$ the marginal cost of the foreign firm's production in the foreign country (possibly including the cost of transportation), and $c_{s}$ the marginal cost of the foreign firm's production at the subsidiary. In order to focus on the role of FDI as tariff jumping, we assume that $c_{f}<c_{s}<c_{f}+\bar{t}$, where $\overline{\mathrm{t}}$ is the prohibitive tariff. Namely, the foreign firm has no incentive to invest if there is no tariff, but it prefers to produce at the subsidiary if the tariff is high enough. Because of the assumption of constant marginal costs, the foreign firm supplies $q_{f}$ only from exports (and no subsidiary production) if $c_{f}+t \leq c_{s}$, and it supplies $q_{f}$ only from the subsidiary (and no exports) if $c_{f}+t>c_{s}$ and if it has set up the subsidiary.

Now, let us describe the timing of the game. At stage 0 , the home firm and the foreign firm are engaged in Cournot competition in the home country, without any protection policy and without any subsidiary production. However, the tariff that may be imposed in the later stage is determined as a function of the exports by the foreign firm in stage 0 . Then, at stage 1, given the size of the tariff, the home firm decides how much to spend for a petition for antidumping duty. The more the home firm spends its resources for the petition, the higher the probability of protection will be. The probability of protection is denoted by $\theta$. At stage 2, after observing the protection seeking of the home firm, the foreign firm decides whether to make FDI before the uncertainty about the protection is resolved. The uncertainty about the protection is resolved after stage 2 (and before stage 3). At stage 3, the home firm and the foreign firm again play the Cournot game in the home country.

\section{Solving the Model}

\subsection{Stage 3: Cournot Competition}

With probability $1-\theta$, the tariff is not imposed. In this case, the home firm chooses $q_{h}$ to maximize its profit $\pi_{h}\left(q_{h}, q_{f}\right)$ :

$$
\pi_{h}\left(q_{h}, q_{f}\right)=p\left(q_{h}+q_{f}\right) q_{h}-c_{h} q_{h}
$$

and the foreign firm chooses $q_{f}$ to maximize its profit $\pi_{f}\left(q_{h}, q_{f}\right)$ :

$$
\pi_{f}\left(q_{h}, q_{f}\right)=p\left(q_{h}+q_{f}\right) q_{f}-c_{f} q_{f} .
$$

We assume that the demand function is "not too convex" so that the profit of each firm is concave in its own quantity 
and that the marginal revenue is decreasing in the quantities of other firms (i.e., the quantities are strategic substitutes). This assumption guarantees the existence of the unique equilibrium. We use $\pi_{h}^{*}\left(c_{f}\right)$ and $\pi_{f}^{*}\left(c_{f}\right)$ to denote the equilibrium profits. (Note 3 )

With probability $\theta$, the tariff $t$ is imposed on exports of the foreign firm. The profit function of the home firm is the same as (1). On the other hand, the profit function of the foreign firm is

$$
p\left(q_{h}+q_{f}\right) q_{f}-c_{s} q_{f}
$$

if it has a subsidiary and if $c_{f}+\mathrm{t}>c_{s}$, and

$$
p\left(q_{h}+q_{f}\right) q_{f}-\left(c_{f}+t\right) q_{f}
$$

if it does not have a subsidiary or if $c_{f}+t \leq c_{s}$. The equilibrium profits are denoted by $\pi_{h}^{*}\left(c_{f}+t\right)$ and $\pi_{f}^{*}\left(c_{f}+t\right)$ if the foreign firm exports, and denoted by $\pi_{h}^{*}\left(c_{s}\right)$ and $\pi_{f}^{*}\left(c_{s}\right)$ if the foreign firm uses its subsidiary.

The assumptions of the strategic substitutes and the concavity of the objective function give the standard comparative statics results: $\pi_{h}{ }^{*}$ is increasing and $\pi_{f}^{*}$ is decreasing in the marginal cost of the foreign firm.

\subsection{Stage 2: FDI Decision of the Foreign Firm}

At stage 2, given the probability of protection, $\theta$, the foreign firm decides whether to make FDI or not. There are three cases. First, if the foreign firm makes FDI and if $c_{f}+t>c_{s}$, its expected profit is

$$
\theta \pi_{\mathrm{f}}^{*}\left(\mathrm{c}_{\mathrm{s}}\right)+(1-\theta) \pi_{\mathrm{f}}^{*}\left(\mathrm{c}_{\mathrm{f}}\right)-\mathrm{k},
$$

where $k>0$ is a fixed cost of FDI. Second, if the foreign firm makes FDI and if $c_{f}+t \leq c_{s}$, its expected profit is given by

$$
\theta \pi_{\mathrm{f}}^{*}\left(\mathrm{c}_{\mathrm{f}}+\mathrm{t}\right)+(1-\theta) \pi_{\mathrm{f}}^{*}\left(\mathrm{c}_{\mathrm{f}}\right)-\mathrm{k} .
$$

Third, if it does not make FDI, its expected profit is

$$
\theta \pi_{\mathrm{f}}^{*}\left(\mathrm{c}_{\mathrm{f}}+\mathrm{t}\right)+(1-\theta) \pi_{\mathrm{f}}^{*}\left(\mathrm{c}_{\mathrm{f}}\right) .
$$

Obviously, the foreign firm does not make FDI when the tariff is small enough that $c_{f}+t \leq c_{s}$. When $c_{f}+t>c_{s}$, however, the foreign firm will make FDI for the anticipatory tariff-jumping purpose if the gain of FDI is larger than the cost of FDI. That is, the foreign firm will make FDI if $\theta\left[\pi_{f}^{*}\left(c_{s}\right)-\pi_{f}^{*}\left(c_{f}+t\right)\right]>k$. Now, define as $\theta_{k}$ the cut-off level of probability above which the foreign firm will make FDI. Namely,

$$
\theta_{\mathrm{k}} \equiv \frac{\mathrm{k}}{\pi_{\mathrm{f}}^{*}\left(\mathrm{c}_{\mathrm{s}}\right)-\pi_{\mathrm{f}}^{*}\left(\mathrm{c}_{\mathrm{f}}+\mathrm{t}\right)}
$$

if $c_{f}+t>c_{s}$. The cut-off probability is increasing in $k$ and $c_{s}$, and decreasing in $t$. For convenience, let $\theta_{k}=1$ if $c_{f}+t \leq c_{s}$. Then, the foreign firm's FDI decision is described as follows: it will make FDI if $\theta>\theta_{k}$, and will not make FDI if $\theta \leq \theta_{k}$. (Note 4)

\subsection{Stage 1: A Petition for Protection}

At stage 1, given the size of the tariff, the home firm decides how much to spend for a petition for protection. As we stated earlier, we assume that the probability of protection at stage 3 depends solely on the spending for a petition, and the probability is an increasing function of the spending. Thus, we can model that the home firm is effectively choosing the probability of protection to maximize its expected profit, with the cost function $Z(\theta)$. That is, $Z(\theta)$ measures the amount of resources spent for obtaining the probability of protection $\theta$. We assume that $Z(\theta)$ is increasing and strictly convex, reflecting diminishing marginal returns for the protection-seeking effort. Also, we assume that $Z(0)=0$.

Because of the FDI opportunity of the foreign firm, the expected profit of the home firm, as a function of $\theta$, may consist of two parts. For $\theta \leq \theta_{k}$, the foreign firm will not make FDI, thus the expected profit of the home firm is given by

$$
\Pi_{h}^{t}(\theta) \equiv \theta \pi_{h}^{*}\left(c_{f}+t\right)+(1-\theta) \pi_{h}^{*}\left(c_{f}\right)-Z(\theta) .
$$

On the other hand, for $\theta>\theta_{k}$, the foreign firm will make FDI, thus the expected profit of the home firm is given by

$$
\Pi_{\mathrm{h}}^{\mathrm{s}}(\theta) \equiv \theta \pi_{\mathrm{h}}^{*}\left(\mathrm{c}_{\mathrm{s}}\right)+(1-\theta) \pi_{\mathrm{h}}^{*}\left(\mathrm{c}_{\mathrm{f}}\right)-\mathrm{Z}(\theta) .
$$

Let $\theta_{t}$ and $\theta_{s}$ denote the probability that maximize (3) and (4) respectively. That is, $\theta_{t}$ satisfies the first-order condition (Note 5)

$$
\pi_{h}^{*}\left(c_{f}+t\right)-\pi_{h}^{*}\left(c_{f}\right)-Z^{\prime}\left(\theta_{t}\right)=0,
$$

and $\theta_{s}$ satisfies the first-order condition 


$$
\pi_{\mathrm{h}}^{*}\left(\mathrm{c}_{\mathrm{s}}\right)-\pi_{\mathrm{h}}^{*}\left(\mathrm{c}_{\mathrm{f}}\right)-\mathrm{Z}^{\prime}\left(\theta_{\mathrm{s}}\right)=0 .
$$

Then, the optimal probability of protection chosen by the home firm, denoted by $\theta^{*}$, is given as follows:

$$
\theta^{*}=\left\{\begin{array}{cc}
\theta_{\mathrm{t}} & \text { if } \theta_{\mathrm{t}} \leq \theta_{\mathrm{k}}, \\
\theta_{\mathrm{k}} & \text { if } \theta_{\mathrm{s}} \leq \theta_{\mathrm{k}}<\theta_{\mathrm{t}}, \text { or if } \theta_{\mathrm{k}}<\theta_{\mathrm{s}} \text { and } \Pi_{\mathrm{h}}^{\mathrm{t}}\left(\theta_{\mathrm{k}}\right) \geq \Pi_{\mathrm{h}}^{\mathrm{s}}\left(\theta_{\mathrm{s}}\right), \\
\theta_{\mathrm{s}} & \text { if } \theta_{\mathrm{k}}<\theta_{\mathrm{s}} \text { and } \Pi_{\mathrm{h}}^{\mathrm{t}}\left(\theta_{\mathrm{k}}\right)<\Pi_{\mathrm{h}}^{\mathrm{s}}\left(\theta_{\mathrm{s}}\right) .
\end{array}\right.
$$

Although this may look complicated, the intuition explained below is quite straightforward.

First, consider $\theta_{k}=1$. In this case, (4) is irrelevant for the home firm choosing $\theta$, since the foreign firm will never make FDI. Therefore, the home firm chooses $\theta_{t}$.

Now, consider $\theta_{k}<1$. Notice that $\theta_{k}<1$ implies $c_{f}+t>c_{s}$, which in turn implies $\pi_{h}{ }^{*}\left(c_{f}+t\right)>\pi_{h}{ }^{*}\left(c_{s}\right)$. Thus, $\Pi_{h}{ }^{t}(\theta)$ is larger than $\Pi_{h}^{s}(\theta)$. Since the foreign firm will make FDI if $\theta>\theta_{k}$, at $\theta_{k}$, the expected profit of the home firm jumps down from $\Pi_{h}^{t}\left(\theta_{k}\right)$ to $\Pi_{h}^{s}\left(\theta_{k}\right)$. However, as long as $\theta_{k}$ is larger than $\theta_{t}$, the FDI opportunity of the foreign firm does not matter to the home firm, since choosing $\theta_{t}$ does not induce the foreign firm to make FDI. That is, FDI of the foreign firm is "blockaded" in this case: the home firm chooses the probability of protection as if the foreign firm had no FDI opportunity, and at the chosen probability, the foreign firm will not make FDI.

If $\theta_{t}>\theta_{k}$, however, the FDI opportunity of the foreign firm matters to the protection-seeking decision of the home firm. Were the home firm to choose $\theta_{t}$, the foreign firm would make FDI, thus $\theta_{t}$ would be no longer optimal. So, instead of $\theta_{t}$, the home firm should choose the probability that "deters" the foreign firm from making FDI. Indeed, when $\theta_{s} \leq \theta_{k}<\theta_{t}$, the optimal probability for the home firm is $\theta_{k}$, the one that is just short of inducing FDI.

Finally, if $\theta_{k}$ is smaller than $\theta_{s}$, the home firm may want to allow, or "accommodate", the foreign firm to make FDI. FDI is still deterred if $\Pi_{h}^{t}\left(\theta_{k}\right) \geq \Pi_{h}^{s}\left(\theta_{s}\right)$, that is, the expected profit of deterring FDI is larger than the expected profit of accommodating FDI. On the other hand, FDI is accommodated if $\Pi_{h}{ }^{t}\left(\theta_{k}\right)<\Pi_{h}^{s}\left(\theta_{s}\right)$.

Here, one notable feature of the optimal choice of $\theta$ is that the home firm may find it optimal to deter FDI. If the foreign firm had no FDI opportunity, the home firm would choose $\theta_{t}$. However, because of the FDI opportunity of the foreign firm, the home firm may choose $\theta_{k}$, which is less than $\theta_{t}$. In this sense, we claim that the mere existence of FDI opportunity, not actual investment, can curb the protection-seeking effort of the home firm.

We can now characterize $\theta^{*}$ in terms of $t$. From the definition of $\theta_{t}$, (see equation (5)), it can be shown that $\theta_{t}$ is increasing in $t$, and that $\theta_{t}=0$ when $t=0$. On the other hand, from the definition of $\theta_{k}$, (see equation (2)), it is seen that $\theta_{k}$ is decreasing in $t$, and that $\theta_{k}=1$ when $t=0$. Therefore, when $t$ is small, $\theta_{t} \leq \theta_{k}$ holds, thus the optimal choice of $\theta$ is $\theta_{t}$. Then, as $t$ rises, eventually $\theta_{k}$ falls below $\theta_{t}$. Let $\hat{\mathrm{t}}$ denote $t$ such that $\theta_{t}(\mathrm{t})=\theta_{k}(\mathrm{t})$. At $\hat{\mathrm{t}}$, the optimal choice of the probability of protection is switched from $\theta_{t}$ to $\theta_{k}$, and for $t>\hat{\mathrm{t}}$, the optimal choice is given by $\theta_{k}$. Finally, as $t$ becomes large, $\theta_{k}$ falls below $\theta_{s}$ (note that $\theta_{s}$ is constant in $t$ ). Then, the home firm may choose $\theta_{s}$ instead of $\theta_{k}$. Whether $\theta_{s}$ is chosen depends on the comparison of $\Pi_{h}^{t}\left(\theta_{k}\right)$ and $\Pi_{h}^{s}\left(\theta_{s}\right)$. Thus, even when $t$ is so large that $\theta_{k}$ is smaller than $\theta_{s}, \theta_{s}$ may not be chosen. We will see this in detail later.

In sum, when $t$ is small, the optimal protection-seeking effort chosen by the home firm is to blockade FDI, and protection-seeking effort increases as the tariff rises. This is because a rise in $t$ increases the gain from protection. As $t$ increases, however, the optimal protection seeking changes from blockading FDI to deterring FDI, and the protection-seeking effort becomes decreasing in the tariff. This is because, as $t$ rises, the foreign firm is going to make FDI at a smaller probability. To keep the foreign firm from making FDI, the home firm has to lower its protection-seeking effort.

Given the optimal level of protection probability presented above, we can now examine the expected profit of the foreign firm. Letting $\Pi_{\mathrm{f}}^{\mathrm{t}}(\theta) \equiv \theta \pi_{\mathrm{f}}^{*}\left(\mathrm{c}_{\mathrm{f}}+\mathrm{t}\right)+(1-\theta) \pi_{\mathrm{f}}^{*}\left(\mathrm{c}_{\mathrm{f}}\right)$ and $\Pi_{\mathrm{f}}^{\mathrm{s}}(\theta) \equiv \theta \pi_{\mathrm{f}}^{*}\left(\mathrm{c}_{\mathrm{s}}\right)+(1-\theta) \pi_{\mathrm{f}}^{*}\left(\mathrm{c}_{\mathrm{f}}\right)-\mathrm{k}$, in Proposition 1 we present the comparative statics for the expected profit of the foreign firm with respect to $t$.

Proposition 1 The expected profit of the foreign firm is decreasing in $t$ when $\theta^{*}=\theta_{t}$, increasing in $t$ when $\theta^{*}=\theta_{k}$, and constant in $t$ when $\theta^{*}=\theta_{s}$.

Proof. When $\theta^{*}=\theta_{t}$, the derivative of the expected profit of the foreign firm with respect to $t$ is given by

$$
\frac{\mathrm{d} \Pi_{\mathrm{f}}^{\mathrm{t}}\left(\theta_{\mathrm{t}}\right)}{\mathrm{dt}}=\theta_{\mathrm{t}} \frac{\partial \pi_{\mathrm{f}}^{*}\left(\mathrm{c}_{\mathrm{f}}+\mathrm{t}\right)}{\partial \mathrm{t}}-\frac{\partial \theta_{\mathrm{t}}}{\partial \mathrm{t}}\left[\pi_{\mathrm{f}}^{*}\left(\mathrm{c}_{\mathrm{f}}\right)-\pi_{\mathrm{f}}^{*}\left(\mathrm{c}_{\mathrm{f}}+\mathrm{t}\right)\right]<0 .
$$

When $\theta^{*}=\theta_{k}$, the derivative of the expected profit of the foreign firm with respect to $t$ is given by 


$$
\frac{\mathrm{d} \Pi_{\mathrm{f}}^{\mathrm{t}}\left(\theta_{\mathrm{k}}\right)}{\mathrm{dt}}=\theta_{\mathrm{k}} \frac{\partial \pi_{\mathrm{f}}^{*}\left(\mathrm{c}_{\mathrm{f}}+\mathrm{t}\right)}{\partial \mathrm{t}}-\frac{\partial \theta_{\mathrm{k}}}{\partial \mathrm{t}}\left[\pi_{\mathrm{f}}^{*}\left(\mathrm{c}_{\mathrm{f}}\right)-\pi_{\mathrm{f}}^{*}\left(\mathrm{c}_{\mathrm{f}}+\mathrm{t}\right)\right]=\theta_{\mathrm{k}} \frac{\partial \pi_{\mathrm{f}}^{*}\left(\mathrm{c}_{\mathrm{f}}+\mathrm{t}\right)}{\partial \mathrm{t}}\left(1-\frac{\pi_{\mathrm{f}}^{*}\left(\mathrm{c}_{\mathrm{f}}\right)-\pi_{\mathrm{f}}^{*}\left(\mathrm{c}_{\mathrm{f}}+\mathrm{t}\right)}{\pi_{\mathrm{f}}^{*}\left(\mathrm{c}_{\mathrm{s}}\right)-\pi_{\mathrm{f}}^{*}\left(\mathrm{c}_{\mathrm{f}}+\mathrm{t}\right)}\right) .
$$

This is positive because $\pi_{f}^{*}\left(c_{f}\right)>\pi_{f}^{*}\left(c_{s}\right)>\pi_{f}^{*}\left(c_{f}+t\right)$ when $\theta^{*}=\theta_{k}$. When $\theta^{*}=\theta_{s}$, the expected profit of the foreign firm is constant in $t$ since $\theta_{s}$ is constant in $t$.

A rise in the tariff affects the expected profit of the foreign firm in two ways: the first effect is through the ex-post profit when the tariff is actually imposed, and the second effect is through the probability of protection. The first effect is always negative since a rise in the tariff lowers the ex-post profit. When FDI is blockaded $\left(\theta^{*}=\theta_{t}\right)$, the second effect is negative too, since a rise in the tariff encourages the protection seeking of the home firm, which increases the likelihood of protection and thus lowers the expected profit of the foreign firm. Since both the first effect and the second effect are negative, the foreign firm is hurt by an increase in the tariff.

On the other hand, when FDI is deterred, the second effect is positive, because a rise in the tariff discourages the protection seeking of the home firm, which decreases the likelihood of protection and thus increases the expected profit of the foreign firm. So, the second effect works in the opposite direction to the first effect. Proposition 1 reveals that the second effect always outweighs the first effect, hence the foreign firm benefits from an increase in the tariff.

Next, let us turn to the comparative statics for the expected profit of the home firm. When the optimal choice of the probability is $\theta_{t}$ or $\theta_{s}$, the comparative statics are simple. First, when $\theta^{*}=\theta_{t}$, the expected profit of the home firm is increasing in $t$, because $\mathrm{d} \Pi_{h}^{t}\left(\theta_{t}\right) / \mathrm{d} t=\theta_{t}\left[\partial \pi_{h}{ }^{*}\left(c_{f}+t\right) / \partial t\right]>0$ by the envelope theorem. Second, when $\theta^{*}=\theta_{s}$, the expected profit of the home firm is independent of $t$, thus a change in $t$ does not affect the profit. However, when $\theta^{*}=\theta_{k}$, whether the expected profit is increasing or decreasing in $t$ is not determinate, because

$$
\frac{\mathrm{d} \Pi_{\mathrm{h}}^{\mathrm{t}}\left(\theta_{\mathrm{k}}\right)}{\mathrm{dt}}=\theta_{\mathrm{k}} \frac{\partial \pi_{\mathrm{h}}^{*}\left(\mathrm{c}_{\mathrm{f}}+\mathrm{t}\right)}{\partial \mathrm{t}}+\frac{\partial \theta_{\mathrm{k}}}{\partial \mathrm{t}}\left[\pi_{\mathrm{h}}^{*}\left(\mathrm{c}_{\mathrm{f}}+\mathrm{t}\right)-\pi_{\mathrm{h}}^{*}\left(\mathrm{c}_{\mathrm{f}}\right)-\mathrm{Z}^{\prime}\left(\theta_{\mathrm{k}}\right)\right] \gtrless 0 .
$$

The first term of equation (7) is positive, but the second term of equation (7) is negative since $\partial \theta_{k} / \partial t<0$ and $\pi_{h}{ }^{*}\left(c_{f}+t\right)-\pi_{h}{ }^{*}\left(c_{f}\right)-Z^{\prime}\left(\theta_{k}\right)>0$. (Note 6) Thus, the expected profit of the home firm can be decreasing in $t$ for some range of $t \in(\hat{t}, \bar{t})$.

Having found this result, we would like to know under what conditions the expected profit of the home firm is decreasing in $t$. To simplify the analysis, suppose that the demand curve is linear, $p=a-b\left(q_{h}+q_{f}\right)$, and that the cost function of the protection-seeking effort is quadratic, $Z(\theta)=\left(z \theta^{2}\right) / 2$ (thus $\left.Z^{\prime}(\theta)=z \theta\right)$. Then, whether the expected profit of the home firm is increasing in $t$ for the whole range of $\mathrm{t} \in[0, \overline{\mathrm{t}}]$ is characterized in terms of $c_{s}, k$, and $z$. In addition, this characterization is useful to see under what conditions $\theta_{s}$ is chosen. Proposition 2 below presents the results. Also, see Figure 1 and Figure 2.

Proposition 2 Suppose that the demand curve is linear and the cost function of the protection-seeking effort is quadratic. Then,

1). for any given $\mathrm{c}_{\mathrm{s}} \in\left(\mathrm{c}_{\mathrm{f}}, \mathrm{c}_{\mathrm{f}}+\overline{\mathrm{t}}\right)$, there exists the corresponding value of $z k$, denoted by $(z k)_{1}$, above which the expected profit of the home firm is increasing in $t$ for the whole range of $\mathrm{t} \in[0, \overline{\mathrm{t}}]$. If $z k \geq(z k)_{1}$, the home firm never chooses $\theta_{s}$;

2). for any given $\mathrm{c}_{\mathrm{s}} \in\left(\mathrm{c}_{\mathrm{f}}, \mathrm{c}_{\mathrm{f}}+\overline{\mathrm{t}}\right)$, there exists the corresponding value of $z k$, denoted by $(z k)_{2}$, below which the home firm chooses $\theta_{s}$ for some $\mathrm{t}>\hat{\mathrm{t}}$.

Proof. See Appendix 1.

$<$ Insert Figure 1 and Figure 2 Here $>$

Proposition 2-1 says that the home firm always gains from an increase in the tariff if $z$ and/or $k$ is large enough. This is understood by looking at equation (8) below, which is the same as equation (7), but in equation (8) we utilize the assumption of the quadratic cost function of protection seeking.

$$
\frac{\mathrm{d} \Pi_{\mathrm{h}}^{\mathrm{t}}\left(\theta_{\mathrm{k}}\right)}{\mathrm{dt}}=\theta_{\mathrm{k}} \frac{\partial \pi_{\mathrm{h}}^{*}\left(\mathrm{c}_{\mathrm{f}}+\mathrm{t}\right)}{\partial \mathrm{t}}+\frac{\partial \theta_{\mathrm{k}}}{\partial \mathrm{t}}\left[\pi_{\mathrm{h}}^{*}\left(\mathrm{c}_{\mathrm{f}}+\mathrm{t}\right)-\pi_{\mathrm{h}}^{*}\left(\mathrm{c}_{\mathrm{f}}\right)\right]-\frac{\partial \theta_{\mathrm{k}}}{\partial \mathrm{t}} \frac{\mathrm{zk}}{\pi_{\mathrm{f}}^{*}\left(\mathrm{c}_{\mathrm{s}}\right)-\pi_{\mathrm{f}}^{*}\left(\mathrm{c}_{\mathrm{f}}+\mathrm{t}\right)} .
$$

A rise in the tariff affects the expected profit of the home firm in three ways. First, a rise in the tariff increases the ex-post profit (the first term in equation (8)). Second, the expected benefit of protection decreases due to the increase in the tariff, since $\theta_{k}$ is decreasing in $t$ (the second term in equation (8)). Third, however, the decrease in $\theta_{k}$ helps the 
home firm, since the cost of obtaining $\theta_{k}$ falls as $\theta_{k}$ decreases (the third term in equation (8)). The size of $z k$ affects only the third term. The larger the $z k$ is, the larger the marginal cost of protection seeking, thus the more the home firm can save by a decrease in $\theta_{k}$. Therefore, equation (8) is likely to be positive when $z k$ is large. Proposition 2-1 also says that $\theta_{s}$ cannot be optimal if $z k$ is large enough. This is simply because the expected profit of accommodating FDI is always less than the expected profit of deterring FDI when the latter is increasing in $t$.

Consequently, for the home firm to choose FDI accommodation as the optimal choice, $z k$ must be small enough that $\Pi_{h}^{t}\left(\theta_{k}\right)$ is decreasing in some $\mathrm{t}>\hat{\mathrm{t}}$, so that $\Pi_{h}^{t}\left(\theta_{k}\right)$ falls below $\Pi_{h}^{s}\left(\theta_{s}\right)$. This is what Proposition 2-2 says. Its intuition is as follows. When the fixed cost of FDI is small, the probability of protection to deter FDI is small, thus deterring FDI becomes less preferable than accommodating FDI. When the marginal cost of protection seeking is small, the probability of protection to accommodate FDI is large, thus accommodating FDI becomes more preferable than deterring FDI.

In Figure 1, we numerically evaluate $(z k)_{1}$ and $(z k)_{2}$ for the case where the demand curve is $p=1-q_{h}-q_{f}$, and the marginal costs of production are $c_{h}=c_{f}=0$. In the diagram, we also show $(z k)_{0}$ curve as a reference. In the region above $(z k)_{0}$ (denoted as Region 0 ), the optimal choice of the probability is always blockading FDI (for derivation of $(z k)_{0}$, see Appendix 2), thus the expected profit of the home firm is increasing in the whole range of $t$. In Region 1, the area below $(z k)_{0}$ and above $(z k)_{1}$, the optimal choice of the protection probability is blockading FDI for small $t$ and deterring FDI for large $t$. FDI is never accommodated no matter how $t$ is large. In this region, the expected profit of the home firm is increasing in the whole range of $t$. In Region 2, the area below $(z k)_{1}$ and above $(z k)_{2}$, the optimal choice of the protection is still blockading or deterring FDI, but the expected profit of the home firm is decreasing for some range of $t$ when FDI is deterred. Finally, in region 3, the area below $(z k)_{2}$, the expected profit of the home firm is decreasing in some $t$ when FDI is deterred, and accommodation of FDI occurs when $t$ is large enough. Figure 2 shows how the shapes of $\Pi_{h}^{t}\left(\theta_{k}\right)$ curves are different in each region of the parameter space given in Figure 1.

Figure 1 demonstrates that FDI accommodation occurs only in a limited area of the parameter space, suggesting that the foreign firm does not make antidumping-duty-jumping FDI very often. This result is consistent with the empirical study of Blonigen (2002), which found that not many firms subject to the U.S. antidumping duties made tariff-jumping FDI.

\subsection{Stage 0: Cournot Competition}

At stage 0 , the home firm and the foreign firm play a Cournot game in the home country, without any protection of the home market and without any subsidiary production by the foreign firm. However, the tariff that may be imposed at stage 3 is an increasing function of the exports of the foreign firm at stage 0: i.e., $t=t\left(q_{f, 0}\right)$ with $t^{\prime}\left(q_{f, 0}\right)>0$, where $q_{f, 0}$ denotes the exports of the foreign firm at stage 0 . As we have explained in the introduction, this assumption comes from the idea that the more exports by the foreign firm lower the price in the home market, and thus are considered as more dumping, resulting in the higher antidumping duty. This endogenous determination of protection gives the foreign firm an incentive to strategically change its exports.

Here, it should be noted that this way of endogenizing antidumping duty is quite incomplete, since the size of antidumping duty can be influenced not only by the exports of the foreign firm, but also by the sales of the home firm and by the price in local market of the foreign firm. Therefore, the foreign firm may have a strategic incentive to change not only its exports but also its behavior in its local market, or the home firm may have a strategic incentive to change its sales in the home market. However, such a more complete modeling of antidumping duty will make our analysis complicated, and is likely to obscure our main point on the strategic response of the foreign firm in its exports. Therefore, we use the simple modeling of antidumping duty described above. Here, we concentrate on the case of Region 1 in Figure 1: i.e., the expected profit of the home firm is ever increasing in $t$, and FDI accommodation does not occur for any $t$. This is because looking at the case of FDI accommodation is not very interesting, as the profit of the foreign firm is constant in $t$ when FDI is accommodated.

Now, let us examine the strategy of each firm in stage 0 . Since the home firm's quantity sold at stage 0 has no intertemporal effect, it simply chooses the quantity of stage 0 to maximize the static profit, $\pi_{h}\left(q_{h}, q_{f}\right)$ (hereafter, we do not use the time subscripts on $q_{h}$ and $q_{f}$ since the quantity variables we see in this subsection are those of stage 0 . Also, we use the notation $\pi_{h}(\cdot)$ and $\pi_{f}(\cdot)$ to denote the profit of stage 0 , and $\pi_{h}^{*}(\cdot)$ and $\pi_{f}^{*}(\cdot)$ to denote the profit of stage 3$)$. The reaction function of the home firm at stage 0 , denoted by $r_{h}\left(q_{f}\right)$, is implicitly defined by $\partial \pi_{h}\left(r_{h}\left(q_{f}\right), q_{f}\right) / \partial q_{h}=0$.

On the other hand, the exports of the foreign firm at stage 0 affect the tariff in stage 3 . The foreign firm thus chooses its exports to maximize the intertemporal profit. When FDI is going to be blockaded, the intertemporal profit of the 
foreign firm is given by

$$
\mathrm{V}_{\mathrm{t}}\left(\mathrm{q}_{\mathrm{h}}, \mathrm{q}_{\mathrm{f}}\right) \equiv \pi_{\mathrm{f}}\left(\mathrm{q}_{\mathrm{h}}, \mathrm{q}_{\mathrm{f}}\right)+\delta\left\{\theta_{\mathrm{t}}\left(\mathrm{t}\left(\mathrm{q}_{\mathrm{f}}\right)\right) \pi_{\mathrm{f}}^{*}\left(\mathrm{c}_{\mathrm{f}}+\mathrm{t}\left(\mathrm{q}_{\mathrm{f}}\right)\right)+\left[1-\theta_{\mathrm{t}}\left(\mathrm{t}\left(\mathrm{q}_{\mathrm{f}}\right)\right)\right] \pi_{\mathrm{f}}^{*}\left(\mathrm{c}_{\mathrm{f}}\right)\right\},
$$

where $\delta \in(0,1)$ is a discount factor. Let $r_{f}^{t}\left(q_{h}\right)$ denote the reaction function of the foreign firm in the case of FDI blockade. The first-order condition of $V_{t}\left(q_{h}, q_{f}\right)$ defines $r_{f}^{t}$ as follows:

$$
\frac{\partial \pi_{\mathrm{f}}\left(\mathrm{q}_{\mathrm{h}}, \mathrm{r}_{\mathrm{f}}^{\mathrm{t}}\right)}{\partial \mathrm{q}_{\mathrm{f}}}+\delta\left(\theta_{\mathrm{t}}\left(\mathrm{t}\left(\mathrm{r}_{\mathrm{f}}^{\mathrm{t}}\right)\right) \frac{\partial \pi_{\mathrm{f}}^{*}\left(\mathrm{c}_{\mathrm{f}}+\mathrm{t}\left(\mathrm{r}_{\mathrm{f}}^{\mathrm{t}}\right)\right)}{\partial \mathrm{t}}-\frac{\partial \theta_{\mathrm{t}}\left(\mathrm{t}\left(\mathrm{r}_{\mathrm{f}}^{\mathrm{t}}\right)\right)}{\partial \mathrm{t}}\left[\pi_{\mathrm{f}}^{*}\left(\mathrm{c}_{\mathrm{f}}\right)-\pi_{\mathrm{f}}^{*}\left(\mathrm{c}_{\mathrm{f}}+\mathrm{t}\left(\mathrm{r}_{\mathrm{f}}^{\mathrm{t}}\right)\right)\right]\right) \mathrm{t}^{\prime}\left(\mathrm{r}_{\mathrm{f}}^{\mathrm{t}}\right)=0 .
$$

We impose a regularity assumption on $V_{t}\left(q_{h}, q_{f}\right)$ that $\partial^{2} V_{t}\left(q_{h}, q_{f}\right) / \partial q_{f}{ }^{2}<\partial^{2} V_{t}\left(q_{h}, q_{f}\right) / \partial q_{f} \partial q_{h}<0$. This assumption guarantees that slope of the reaction function $r_{f}^{t}\left(q_{h}\right)$ is negative and less than 1 in absolute value, as it is so in the standard Cournot model.

When FDI is going to be deterred, the intertemporal profit of the foreign firm is given by

$$
\mathrm{V}_{\mathrm{k}}\left(\mathrm{q}_{\mathrm{h}}, \mathrm{q}_{\mathrm{f}}\right) \equiv \pi_{\mathrm{f}}\left(\mathrm{q}_{\mathrm{h}}, \mathrm{q}_{\mathrm{f}}\right)+\delta\left\{\theta_{\mathrm{k}}\left(\mathrm{t}\left(\mathrm{q}_{\mathrm{f}}\right)\right) \pi_{\mathrm{f}}^{*}\left(\mathrm{c}_{\mathrm{f}}+\mathrm{t}\left(\mathrm{q}_{\mathrm{f}}\right)\right)+\left[1-\theta_{\mathrm{k}}\left(\mathrm{t}\left(\mathrm{q}_{\mathrm{f}}\right)\right)\right] \pi_{\mathrm{f}}^{*}\left(\mathrm{c}_{\mathrm{f}}\right)\right\}
$$

Let $r_{f}^{k}\left(q_{h}\right)$ denote the reaction function of the foreign firm in the case of FDI deterrence. The first-order condition of $V_{k}\left(q_{h}, q_{f}\right)$ defines $r_{f}^{k}$ as follows:

$$
\frac{\partial \pi_{\mathrm{f}}\left(\mathrm{q}_{\mathrm{h}}, \mathrm{r}_{\mathrm{f}}^{\mathrm{k}}\right)}{\partial \mathrm{q}_{\mathrm{f}}}+\delta \frac{\partial \theta_{\mathrm{k}}\left(\mathrm{t}\left(\mathrm{r}_{\mathrm{f}}^{\mathrm{k}}\right)\right)}{\partial \mathrm{t}}\left[\pi_{\mathrm{f}}^{*}\left(\mathrm{c}_{\mathrm{s}}\right)-\pi_{\mathrm{f}}^{*}\left(\mathrm{c}_{\mathrm{f}}\right)\right] \mathrm{t}^{\prime}\left(\mathrm{r}_{\mathrm{f}}^{\mathrm{k}}\right)=0
$$

We impose a similar regularity assumption on $V_{k}\left(q_{h}, q_{f}\right)$ in order to guarantee that the slope of $r_{f}^{k}\left(q_{h}\right)$ is negative and less than 1 in absolute value.

As a reference, consider the reaction function of the foreign firm when the future tariff is independent of $q_{f}$. Let $r_{f}\left(q_{h}\right)$ denote such a reaction function. Since the future profit becomes independent of $q_{f}$ in this case, the reaction function $r_{f}\left(q_{h}\right)$ is defined simply by the first-order condition of a static Cournot game: $\partial \pi_{f}\left(q_{h}, r_{f}\right) / \partial q_{f}=0$.

By inspection, one can see that the second term on the left-hand side of equation (9) is negative, while the second term on the left-hand side of equation (10) is positive. Since the intertemporal profit function is concave, it is readily derived that $r_{f}^{t}\left(q_{h}\right)<r_{f}\left(q_{h}\right)<r_{f}^{k}\left(q_{h}\right)$ : on one hand, if the home firm is going to blockade FDI, then the foreign firm has an incentive to decrease its exports below the static best-reaction level; on the other hand, if the home firm is going to deter FDI, the foreign firm has an incentive to increase its exports above the static best-reaction level.

Those two different incentives to deviate from the static reaction function give the following two possible equilibria (See Figure 3). One equilibrium occurs at the intersection of $r_{h}\left(q_{f}\right)$ and $r_{f}^{t}\left(q_{h}\right)$, denoted by $\left(q_{h}^{t}, q_{f}^{t}\right)$. In this equilibrium, the quantity of the foreign firm's exports is smaller than the static equilibrium quantity. Facing the future protection, the foreign firm strategically reduces its exports, so as to lower the future tariff and lower the protection seeking of the home firm. The other equilibrium occurs at the intersection of $r_{h}\left(q_{f}\right)$ and $r_{f}^{k}\left(q_{h}\right)$, denoted by $\left(q_{h}{ }^{k}, q_{f}^{k}\right)$. In this equilibrium, the quantity of the exports is larger than the static equilibrium quantity. Facing the future protection, the foreign firm strategically increases its exports to raise the future tariff. By raising the future tariff, the foreign firm can make itself ready to make FDI at a smaller level of protection probability. Then, the home firm, which wants to deter FDI, will lower its protection seeking. Proposition 3 below formally gives under what conditions each equilibrium occurs. Also, see Figure 3.

$<$ Insert Figure 3 Here $>$

Proposition 3 Let $\tilde{\mathrm{q}}_{\mathrm{h}}$ be the value of $q_{h}$ such that the foreign firm is indifferent between exporting $r_{f}^{t}\left(q_{h}\right)$ and exporting $r_{f}^{k}\left(q_{h}\right)$. That is, $V_{t}\left(q_{h}, r_{f}^{t}\left(q_{h}\right)\right)=\mathrm{V}_{k}\left(q_{h}, r_{f}^{k}\left(q_{h}\right)\right)$.

1). If $\tilde{q}_{h}<q_{h}^{k}$, then $\left(q_{h}^{t}, q_{f}^{t}\right)$ is the unique equilibrium.

2). If $\tilde{q}_{h}>q_{h}^{t}$, then $\left(q_{h}^{k}, q_{f}^{k}\right)$ is the unique equilibrium.

3). If $q_{h}^{k} \leq \tilde{q}_{h}<q_{h}^{t}$, then both $\left(q_{h}^{t}, q_{f}^{t}\right)$ and $\left(q_{h}^{k}, q_{f}^{k}\right)$ are the equilibria.

Proof. Since the slopes of the reaction functions are negative and less than 1 in absolute value, and since $r_{f}^{t}\left(q_{h}\right)<$ $r_{f}^{k}\left(q_{h}\right)$, it is seen that $q_{h}{ }^{k}$ is less than $q_{h}{ }^{t}$. Then, it suffices to show that the reaction function of the foreign firm is given by $r_{f}^{t}\left(q_{h}\right)$ when $\mathrm{q}_{\mathrm{h}} \geq \tilde{\mathrm{q}}_{\mathrm{h}}$, and it is given by $r_{f}^{k}\left(q_{h}\right)$ when $\mathrm{q}_{\mathrm{h}} \leq \tilde{\mathrm{q}}_{\mathrm{h}}$. Differentiating $V_{t}\left(q_{h}, r_{f}^{t}\left(q_{h}\right)\right)-\mathrm{V}_{k}\left(q_{h}, r_{f}^{k}\left(q_{h}\right)\right)$ with respect to $q_{h}$,

$$
\frac{d\left[V_{t}\left(q_{h}, r_{f}^{t}\left(q_{h}\right)\right)-V_{k}\left(q_{h}, r_{f}^{k}\left(q_{h}\right)\right)\right]}{d q_{h}}=\frac{\partial \pi_{f}\left(q_{h}, r_{f}^{t}\left(q_{h}\right)\right)}{\partial q_{h}}-\frac{\partial \pi_{f}\left(q_{h}, r_{f}^{k}\left(q_{h}\right)\right)}{\partial q_{h}}
$$


by the envelope theorem. This is positive since $\partial^{2} \pi_{f}\left(q_{h}, q_{f}\right) / \partial q_{h} \partial q_{f}<0$ and $r_{f}^{t}\left(q_{h}\right)<r_{f}^{k}\left(q_{h}\right)$. Thus, the larger $q_{h}$ is, the more profitable for the foreign firm to choose $r_{f}^{t}\left(q_{h}\right)$ rather than $r_{f}^{k}\left(q_{h}\right)$. Hence, the reaction function of the foreign firm is given by $r_{f}^{t}\left(q_{h}\right)$ when $\mathrm{q}_{\mathrm{h}} \geq \tilde{\mathrm{q}}_{\mathrm{h}}$, and given by $r_{f}^{k}\left(q_{h}\right)$ when $\mathrm{q}_{\mathrm{h}} \leq \tilde{\mathrm{q}}_{\mathrm{h}}$, as claimed.

Proposition 3 says that $\left(q_{h}{ }^{k}, q_{f}^{k}\right)$ is the unique equilibrium if $\tilde{\mathrm{q}}_{\mathrm{h}}$ is larger than $q_{h}{ }^{t}$. From the definition of $\tilde{\mathrm{q}}_{\mathrm{h}}$ and $q_{h}{ }^{t}$, it is straightforward to show that $\partial \tilde{\mathrm{q}}_{\mathrm{h}} / \partial \mathrm{k}<0$ and $\partial \tilde{\mathrm{q}}_{\mathrm{h}} / \partial \mathrm{c}_{\mathrm{s}}<0$, while $\partial q_{h}{ }^{t} / \partial k=0$ and $\partial q_{h}{ }^{t} / \partial c_{s}=0$. Thus, when the fixed cost of FDI or the marginal cost of subsidiary production is small enough, the strategic increase in the exports occurs as the unique equilibrium. Intuitively, the smaller $k$ or the smaller $c_{s}$ is, the more likely the optimal probability of protection chosen by the home firm is to deter FDI, thus the more likely the foreign firm is to engage in strategic increase in the exports.

Whether $\left(q_{h}^{k}, q_{f}^{k}\right)$ is the unique equilibrium also depends on the shape of the tariff function, $t\left(q_{f}\right)$. For example, suppose that $\mathrm{t}(0) \geq \hat{\mathrm{t}}$. Then, the probability of protection chosen by the home firm is to deter FDI no matter how much the foreign firm exports. In this extreme case, $\left(q_{h}{ }^{k}, q_{f}{ }^{k}\right)$ is the unique equilibrium. This suggests that the strategic increase in the exports is likely to occur if the home government is going to impose a high tariff even when $q_{f}$ is small.

\section{Concluding Remarks}

This paper analyzed how the protection-seeking effort of the import-competing firm, in the form of an antidumping petition, is affected by the FDI opportunity of the foreign firm. We have shown that the optimal level of protection-seeking effort chosen by the home firm is either blockading FDI, deterring FDI, or accommodating FDI. An interesting result derived in this paper is that when the optimal choice is to deter FDI, the home firm decreases its protection-seeking effort as the tariff increases. An implication of this inverse relationship between the tariff and the protection-seeking effort is that an increase in the tariff can benefit the foreign firm.

When the protection is endogenized in a way that the future tariff depends on the current exports of the foreign firm, the foreign firm will strategically change its exports in order to lower the protection-seeking effort of the home firm. The second point of the paper is that the direction of the strategic change in the exports of the foreign firm is not uniform. If the cost of investment is high, FDI is likely to be blockaded, so that the foreign firm strategically decreases its exports to lower the protection-seeking effort of the home firm. On the other hand, if the cost of investment is low enough, FDI is likely to be deterred, so that the foreign firm strategically increases its exports to lower the protection-seeking effort of the home firm.

Antidumping policy, as it is widely believed, has an effect of curbing the exports of the foreign firm. However, our results suggest that it is not always the case. When the foreign firm has an FDI opportunity, antidumping policy may encourage the foreign firms to export more, contrary to the intention of the policy.

\section{Appendix 1: Proof of proposition 2}

\section{Proof of proposition 2-1}

When $Z(\theta)=\left(z \theta^{2}\right) / 2$, equation $(7)$ can be rewritten as

$$
\frac{\mathrm{d} \Pi_{\mathrm{h}}^{\mathrm{t}}\left(\theta_{\mathrm{k}}\right)}{\mathrm{dt}}=\theta_{\mathrm{k}} \frac{\partial \pi_{\mathrm{h}}^{*}\left(\mathrm{c}_{\mathrm{f}}+\mathrm{t}\right)}{\partial \mathrm{t}}+\frac{\partial \theta_{\mathrm{k}}}{\partial \mathrm{t}}\left[\pi_{\mathrm{h}}^{*}\left(\mathrm{c}_{\mathrm{f}}+\mathrm{t}\right)-\pi_{\mathrm{h}}^{*}\left(\mathrm{c}_{\mathrm{f}}\right)-\mathrm{z} \theta_{\mathrm{k}}\right]=\mathrm{A}\left(\mathrm{t}, \mathrm{c}_{\mathrm{s}}\right)\left[\mathrm{zk}-\mathrm{X}\left(\mathrm{t}, \mathrm{c}_{\mathrm{s}}\right)\right],
$$

where

$$
\begin{aligned}
& A\left(t, c_{s}\right)=-\frac{\theta_{k}}{\left[\pi_{f}^{*}\left(c_{s}\right)-\pi_{f}^{*}\left(c_{f}+t\right)\right]^{2}} \frac{\partial \pi_{f}^{*}\left(c_{f}+t\right)}{\partial t} \text {, and } \\
& \quad X\left(t, c_{s}\right)=\left[\pi_{f}^{*}\left(c_{s}\right)-\pi_{f}^{*}\left(c_{f}+t\right)\right]^{2}\left(\frac{\partial \pi_{h}^{*}\left(c_{f}+t\right)}{\partial t} / \frac{\partial \pi_{f}^{*}\left(c_{f}+t\right)}{\partial t}\right)+\left[\pi_{f}^{*}\left(c_{s}\right)-\pi_{f}^{*}\left(c_{f}+t\right)\right]\left[\pi_{h}^{*}\left(c_{f}+t\right)-\pi_{h}^{*}\left(c_{f}\right)\right] .
\end{aligned}
$$

Since $A\left(t, c_{s}\right)>0$, it can be seen that $\mathrm{d} \Pi_{h}^{t}\left(\theta_{k}\right) / \mathrm{d} t \geq 0$ for the range of $\mathrm{t} \in[\hat{\mathrm{t}}, \overline{\mathrm{t}}]$ if and only if

$\mathrm{zk} \geq \max _{\mathrm{t} \in[\hat{\mathrm{t}} \mathrm{t}]} \mathrm{X}\left(\mathrm{t}, \mathrm{c}_{\mathrm{s}}\right)$.

Note that $X\left(t, c_{s}\right)=0$ when $t=c_{s}-c_{f}$. In addition, when the demand curve is linear, it is tedious but straightforward to show that $(\partial \mathrm{X} / \partial \mathrm{t})_{\mathrm{t}=\mathrm{c}_{\mathrm{s}}-\mathrm{c}_{\mathrm{f}}}>0, \lim _{\mathrm{t} \rightarrow \mathrm{t}} \mathrm{X}\left(\mathrm{t}, \mathrm{c}_{\mathrm{s}}\right)=-\infty, \lim _{\mathrm{t} \rightarrow \overline{\mathrm{t}}}(\partial \mathrm{X} / \partial \mathrm{t})=-\infty$, and $\partial^{2} \mathrm{X} / \partial \mathrm{t}^{2}<0$ for $\mathrm{t} \in\left[\mathrm{c}_{\mathrm{s}}-\mathrm{c}_{\mathrm{f}}, \overline{\mathrm{t}}\right]$. Hence, $X\left(t, c_{s}\right)$ has the unique maximum at some $\mathrm{t} \in\left[\mathrm{c}_{\mathrm{s}}-\mathrm{c}_{\mathrm{f}}, \overline{\mathrm{t}}\right]$. Let $t_{X}$ denote $t$ that maximizes $X\left(t, c_{s}\right)$. Then, we define $(z k)_{1} \equiv X\left(t_{X}, c_{s}\right)$. 
For this definition of $(z k)_{1}$ to be valid, it needs to be confirmed that $t_{X} \geq \hat{\mathrm{t}}$ when $z k=(z k)_{1}$ (this is because $\hat{\mathrm{t}}$ depends on $z k$ ). Since $\theta_{t}=\left[\pi_{h}{ }^{*}\left(c_{f}+t\right)-\pi_{h}{ }^{*}\left(c_{f}\right)\right] / z$ and $\theta_{k}=k /\left[\pi_{f}^{*}\left(c_{s}\right)-\pi_{f}^{*}\left(c_{f}+\mathrm{t}\right)\right]$, when $z k=(z k)_{1}, \hat{\mathrm{t}}$ satisfies $\left[\pi_{\mathrm{h}}^{*}\left(\mathrm{c}_{\mathrm{f}}+\hat{\mathrm{t}}\right)-\pi_{\mathrm{h}}^{*}\left(\mathrm{c}_{\mathrm{f}}\right)\right]\left[\pi_{\mathrm{f}}^{*}\left(\mathrm{c}_{\mathrm{s}}\right)-\pi_{\mathrm{f}}^{*}\left(\mathrm{c}_{\mathrm{f}}+\hat{\mathrm{t}}\right)\right]=(\mathrm{zk})_{1}$.

The following chain of inequalities

$$
\begin{gathered}
{\left[\pi_{\mathrm{h}}^{*}\left(\mathrm{c}_{\mathrm{f}}+\hat{\mathrm{t}}\right)-\pi_{\mathrm{h}}^{*}\left(\mathrm{c}_{\mathrm{f}}\right)\right]\left[\pi_{\mathrm{f}}^{*}\left(\mathrm{c}_{\mathrm{s}}\right)-\pi_{\mathrm{f}}^{*}\left(\mathrm{c}_{\mathrm{f}}+\hat{\mathrm{t}}\right)\right]=(\mathrm{zk})_{1}=\mathrm{X}\left(\mathrm{t}_{\mathrm{X}}, \mathrm{c}_{\mathrm{s}}\right)} \\
<\left[\pi_{\mathrm{h}}^{*}\left(\mathrm{c}_{\mathrm{f}}+\mathrm{t}_{\mathrm{X}}\right)-\pi_{\mathrm{h}}^{*}\left(\mathrm{c}_{\mathrm{f}}\right)\right]\left[\pi_{\mathrm{f}}^{*}\left(\mathrm{c}_{\mathrm{s}}\right)-\pi_{\mathrm{f}}^{*}\left(\mathrm{c}_{\mathrm{f}}+\mathrm{t}_{\mathrm{X}}\right)\right]
\end{gathered}
$$

confirms that $t_{X} \geq \hat{\mathrm{t}}$ when $z k=(z k)_{1}$, since $\left[\pi_{h}^{*}\left(c_{f}+\mathrm{t}\right)-\pi_{h} *\left(c_{f}\right)\right]\left[\pi_{f}^{*}\left(c_{s}\right)-\pi_{f}^{*}\left(c_{f}+t\right)\right]$ is increasing in $t$.

Finally, note that $\prod_{h}^{t}\left(\theta_{k}\right)=\Pi_{h}^{t}\left(\theta_{t}\right)>\Pi_{h}^{s}\left(\theta_{s}\right)$ at $t=\hat{\mathrm{t}}$. Since $\mathrm{d} \Pi_{h}^{t}\left(\theta_{k}\right) / \mathrm{d} t>0$ for $\mathrm{t} \in[\hat{\mathrm{t}}, \overline{\mathrm{t}}]$ if $z k>(z k)_{1}$, we have $\Pi_{h}^{t}\left(\theta_{t}\right)>\Pi_{h}^{s}\left(\theta_{s}\right)$ for $\mathrm{t} \in[\hat{\mathrm{t}}, \overline{\mathrm{t}}]$. Therefore, $\theta_{s}$ is never chosen if $z k>(z k)_{1}$.

\section{Proof of proposition 2-2}

For some $t>\hat{\mathrm{t}}$, the home firm chooses $\theta_{s}$ if

$$
\Pi_{\mathrm{h}}^{\mathrm{s}}\left(\theta_{\mathrm{s}}\right)>\min _{\mathrm{t} \in[\mathrm{t}, \mathrm{t}]} \Pi_{\mathrm{h}}^{\mathrm{t}}\left(\theta_{\mathrm{k}}(\mathrm{t}), \mathrm{t}\right)
$$

From equation (A1), it is seen that $\mathrm{d} \prod_{h}^{t}\left(\theta_{k}\right) / \mathrm{d} t=0$ if and only if $z k=X\left(t, c_{s}\right)$. Since $X\left(t, c_{s}\right)$ is single-peaked in the range of $\mathrm{t} \in[\hat{\mathrm{t}}, \overline{\mathrm{t}}]$, there are at most two $t^{\prime}$ s that satisfy $z k=X\left(t, c_{s}\right)$. Let $\mathrm{t}_{0}^{-}$and $\mathrm{t}_{0}^{+}$, with $\mathrm{t}_{0}^{-} \leq \mathrm{t}_{0}^{+}$denote such $t$ 's. Since $\mathrm{t}_{0}^{-} \leq \mathrm{t}_{\mathrm{X}} \leq \mathrm{t}_{0}^{+}$and since $\partial X / \partial t=0$ at $t_{X}$, we know that $\partial X / \partial t>0$ at $\mathrm{t}_{0}^{-}$and $\partial X / \partial t<0$ at $\mathrm{t}_{0}^{+}$. This means that $\mathrm{d}^{2} \prod_{h}^{t}\left(\theta_{k}\right) / \mathrm{d} t^{2} \leq 0$ at $t=\mathrm{t}_{0}^{-}$, and $\mathrm{d}^{2} \prod_{h}^{t}\left(\theta_{k}\right) / \mathrm{d} t^{2} \geq 0$ at $t=\mathrm{t}_{0}^{+}$. Thus, For $\mathrm{t} \in[\hat{\mathrm{t}}, \overline{\mathrm{t}}]$, there is the unique minimum of $\prod_{h}^{t}\left(\theta_{k}\right)$ at $t=\mathrm{t}_{0}^{+}$. Noticing that $\theta_{s}=\left[\pi_{h}^{*}\left(c_{s}\right)-\pi_{h}{ }^{*}\left(c_{f}\right)\right] / \mathrm{z}$, and evaluating $\Pi_{h}^{t}\left(\theta_{k}\right)$ at $\mathrm{t}_{0}^{+}$, equation (A2) is rewritten as

$$
\frac{\left[\pi_{\mathrm{h}}^{*}\left(\mathrm{c}_{\mathrm{s}}\right)-\pi_{\mathrm{h}}^{*}\left(\mathrm{c}_{\mathrm{f}}\right)\right]^{2}}{2}>\frac{\mathrm{zk}}{\pi_{\mathrm{f}}^{*}\left(\mathrm{c}_{\mathrm{s}}\right)-\pi_{\mathrm{f}}^{*}\left(\mathrm{c}_{\mathrm{f}}+\mathrm{t}_{0}^{+}\right)}\left\{\left[\pi_{\mathrm{h}}^{*}\left(\mathrm{c}_{\mathrm{f}}+\mathrm{t}_{0}^{+}\right)-\pi_{\mathrm{h}}^{*}\left(\mathrm{c}_{\mathrm{f}}\right)\right]-\frac{\mathrm{zk}}{2\left[\pi_{\mathrm{f}}^{*}\left(\mathrm{c}_{\mathrm{s}}\right)-\pi_{\mathrm{f}}^{*}\left(\mathrm{c}_{\mathrm{f}}+\mathrm{t}_{0}^{+}\right)\right]}\right\} .
$$

$(z k)_{2}$ is defined as the value of $z k$ below which this inequality holds. That is,

$$
\begin{aligned}
(\mathrm{zk})_{2}=\left[\pi_{\mathrm{h}}^{*}\left(\mathrm{c}_{\mathrm{f}}+\mathrm{t}_{0}^{+}\right)-\pi_{\mathrm{h}}^{*}\left(\mathrm{c}_{\mathrm{f}}\right)\right]\left[\pi_{\mathrm{f}}^{*}\left(\mathrm{c}_{\mathrm{s}}\right)-\pi_{\mathrm{f}}^{*}\left(\mathrm{c}_{\mathrm{f}}+\mathrm{t}_{0}^{+}\right)\right] & \\
- & {\left[\pi_{\mathrm{f}}^{*}\left(\mathrm{c}_{\mathrm{s}}\right)-\pi_{\mathrm{f}}^{*}\left(\mathrm{c}_{\mathrm{f}}+\mathrm{t}_{0}^{+}\right)\right] \sqrt{\left[\pi_{\mathrm{h}}^{*}\left(\mathrm{c}_{\mathrm{f}}+\mathrm{t}_{0}^{+}\right)-\pi_{\mathrm{h}}^{*}\left(\mathrm{c}_{\mathrm{f}}\right)\right]^{2}-\left[\pi_{\mathrm{h}}^{*}\left(\mathrm{c}_{\mathrm{s}}\right)-\pi_{\mathrm{h}}^{*}\left(\mathrm{c}_{\mathrm{f}}\right)\right]^{2}} }
\end{aligned}
$$

Since $\mathrm{t}_{0}^{+}$depends on $z k$, the equality (A3) implicitly defines $(z k)_{2}$.

\section{Appendix 2: Derivation of $(z k)_{0}$}

The optimal choice of the probability is given by $\theta_{t}$ for the whole range of $t \in[0, \overline{\mathrm{t}}]$ if $\theta_{t}(\overline{\mathrm{t}}) \leq \theta_{k}(\overline{\mathrm{t}})$. So, $(z k)_{0}$ curve, above which the optimal choice is always $\theta_{t}$, is defined by $\theta_{t}(\overline{\mathrm{t}})=\theta_{k}(\overline{\mathrm{t}})$. Rearranging this equality, we obtain $(\mathrm{zk})_{0}=\left[\pi_{\mathrm{h}}^{*}\left(\mathrm{c}_{\mathrm{f}}+\overline{\mathrm{t}}\right)-\pi_{\mathrm{h}}^{*}\left(\mathrm{c}_{\mathrm{f}}\right)\right] \pi_{\mathrm{f}}^{*}\left(\mathrm{c}_{\mathrm{s}}\right)$.

\section{References}

Anderson, James E. (1992). Domino Dumping I: Competitive Exporters. American Economic Review, 82, 65-83.

Anderson, James E. (1993). Domino Dumping II: Anti-dumping. Journal of International Economics, 35, 133-150. http://dx.doi.org/10.1016/0022-1996(93)90008-L

Baldwin, Robert E., \& Moore, Michael O. (1991). Political Aspects of the Administration of the Trade Remedy Laws. In Richard Boltuck and Robert E. Litan (Eds.), Down in the Dumps: Administration of the Unfair Trade Laws (pp. 253-280). Washington, D.C.: the Brookings Institution.

Belderbos, R., Vandenbussche, H., \& Veugelers R. (2004). Antidumping Duties, Undertakings, and Foreign Direct Investment in the EU. European Economic Review, 48, 429-453. http://dx.doi.org/10.1016/S0014-2921(02)00323-9

Bhagwati, Jagdish N., \& Srinivasan, T. N. (1976). Optimal Trade Policy and Compensation Under Endogenous Uncertainty: The Phenomenon of Market Disruption. Journal of International Economics, 6, 317-336. http://dx.doi.org/10.1016/0022-1996(76)90033-7

Bhagwati, Jagdish N., Brecher, Richard A., Dinopoulos, Elias, \& Srinivasan, T. N. (1987). Quid Pro Quo Foreign Investment and Welfare. Journal of Development Economics, 27, 127-138. http://dx.doi.org/10.1016/0304-3878(87)90010-1

Blonigen, Bruce A. (2002). Tariff-jumping Antidumping Duties. Journal of International Economics, 57, 31-49. http://dx.doi.org/10.1016/S0022-1996(01)00135-0 
Blonigen, Bruce A., \& Ohno, Yuka. (1998). Endogenous Protection, Foreign Direct Investment and Protection-Building Trade. Journal of International Economics, 46, 205-227. http://dx.doi.org/10.1016/S0022-1996(97)00042-1

Brander, James A., \& Spencer, Barbara J. (1987). Foreign Direct Investment with Unemployment and Endogenous Taxes and Tariffs. Journal of International Economics, 22, 257-279. http://dx.doi.org/10.1016/S0022-1996(87)80023-5

Ellingsen, Tore, \&Warneryd, Karl. (1999). Foreign Direct Investment and the Political Economy of Protection. International Economic Review, 40, 357-379. http://dx.doi.org/10.1111/1468-2354.00019

Finger, J. Michael, Hall, H. Keith, \& Nelson, Douglas R. (1982). The Political Economy of Administered Protection. American Economic Review, 72, 452-466.

Finger, J. Michael, \& Murry, Tracy. (1993). Antidumping and Countervailing Duty Enforcement in the United States. In J. Michael Finger (Ed.), Antidumping: How It Works and Who Gets Hurt (pp. 241-254). Ann Arbor: MI: The University of Michigan Press.

Fischer, Ronald D. (1992). Endogenous Probability of Protection and Firm Behavior. Journal of International Economics, 32, 149-163. http://dx.doi.org/10.1016/0022-1996(92)90040-Q

Grossman, Gene M., \& Helpman, Elhanan. (1996). Foreign Investment and Endogenous Protection. In R.. Feenstra, G. M. Grossman and D. Irwin (Eds.), The Economy of Trade Policy (pp. 199-223). Cambridge: MA: The MIT Press.

Haaland, Jan I., \&Wooton, Ian. (1998). Antidumping Jumping: Reciprocal Antidumping and Industrial Location. Weltwirtschaftliches Archiv, 134, 340-362. http://dx.doi.org/10.1007/BF02708100

Kayalicaz, M. Özgür, \& Lahiri, Sajal. (2007). Domestic Lobbying and Foreign Direct Investment. The Role of Policy Instruments. Journal of International Trade \& Economic Development, 16, 299-323. http://dx.doi.org/10.1080/09638190701524316

Konishi, Hideo, Saggi, Kamal, \& Weber, Shlomo. (1999). Endogenous Trade Policy under Foreign Direct Investment. Journal of International Economics, 49, 289-308. http://dx.doi.org/10.1016/S0022-1996(98)00066-X

Motta, Massimo. (1992). Multinational Firms and the Tariff-jumping Argument: A Game Theoretic Analysis with Some Unconventional Conclusions. European Economic Review, 36, 1557-1571. http://dx.doi.org/10.1016/0014-2921(92)90006-I

Reitzes, James D. (1993). Antidumping Policy. International Economic Review, 34, 745-763. http://dx.doi.org/10.2307/2526964

Smith, Alasdair. (1987). Strategic Investment, Multinational Corporations and Trade Policy. European Economic Review, 31, 89-96. http://dx.doi.org/10.1016/0014-2921(87)90018-3

Wong, Kar-yiu. (1989). Optimal Threat of Trade Restriction and Quid Pro Quo Foreign Investment. Economics and Politics, 1, 277-300. http://dx.doi.org/10.1111/j.1468-0343.1989.tb00018.x

\section{Notes}

Note 1. We use the word "duty" and "tariff" interchangeably.

Note 2. See Baldwin and Moore (1991), and Finger, Hall and Nelson (1982).

Note 3. Although the equilibrium profits depend on $c_{h}$ as well as $c_{f}$, we suppress $c_{h}$ from the expression of $\pi_{h}{ }^{*}$ and $\pi_{f}{ }^{*}$ since the marginal cost of the home firm is unchanged throughout the paper.

Note 4. We assume that the FDI does not take place if the foreign firm is indifferent between investing and not investing.

Note 5. The second-order condition is satisfied since $Z(\theta)$ is convex.

Note 6. The reason why $\pi_{h}{ }^{*}\left(c_{f}+t\right)-\pi_{h}{ }^{*}\left(c_{f}\right)-Z^{\prime}\left(\theta_{k}\right)>0$ is as follows. Note that $\pi_{h}{ }^{*}\left(c_{f}+t\right)-\pi_{h}{ }^{*}\left(c_{f}\right)-Z^{\prime}\left(\theta_{k}\right)$ is the marginal expected profit of the home firm evaluated at $\theta_{k}$. The marginal expected profit is zero at $\theta_{t}$ by the first-order condition. Since $\theta_{k}<\theta_{t}$ when $\theta^{*}=\theta_{k}, \pi_{h}{ }^{*}\left(c_{f}+t\right)-\pi_{h}{ }^{*}\left(c_{f}\right)-Z^{\prime}\left(\theta_{k}\right)>0$ by the concavity of the expected profit. 


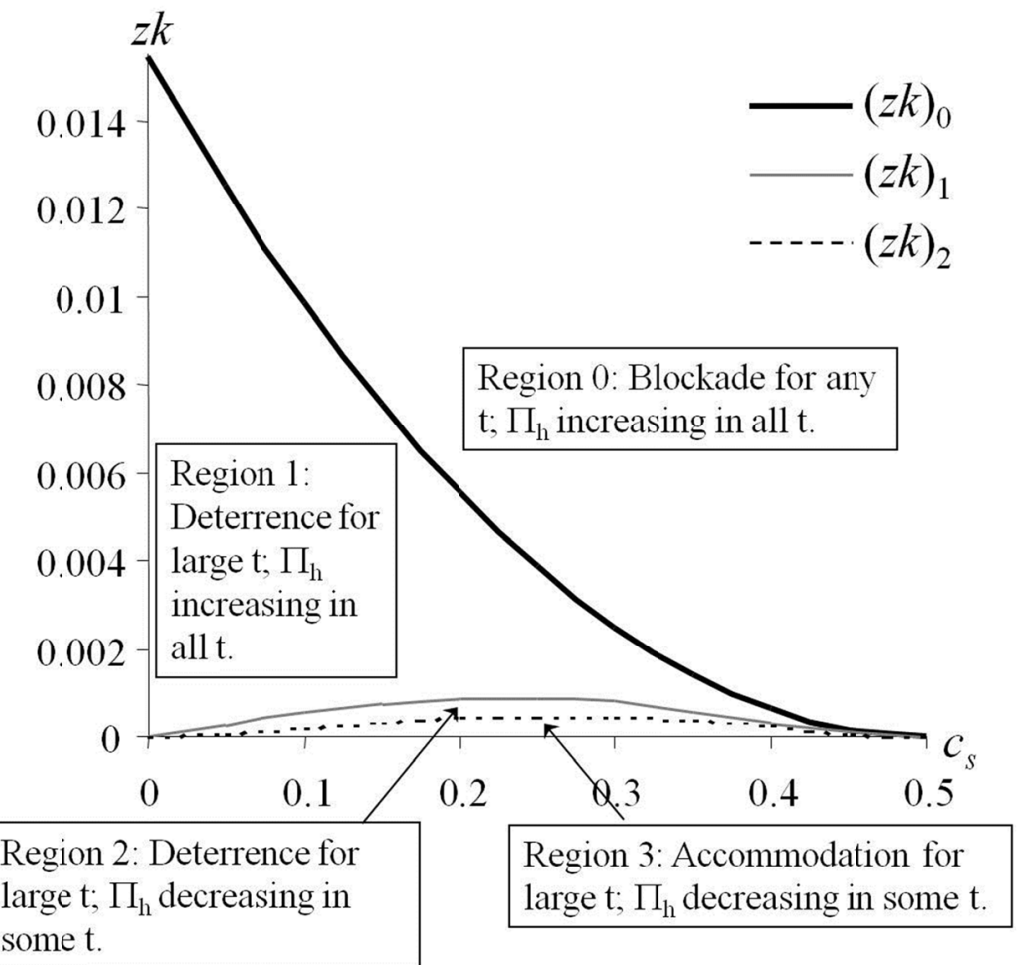

Figure 1. The condition under which the expected profit of the home firm is decreasing in some $t$

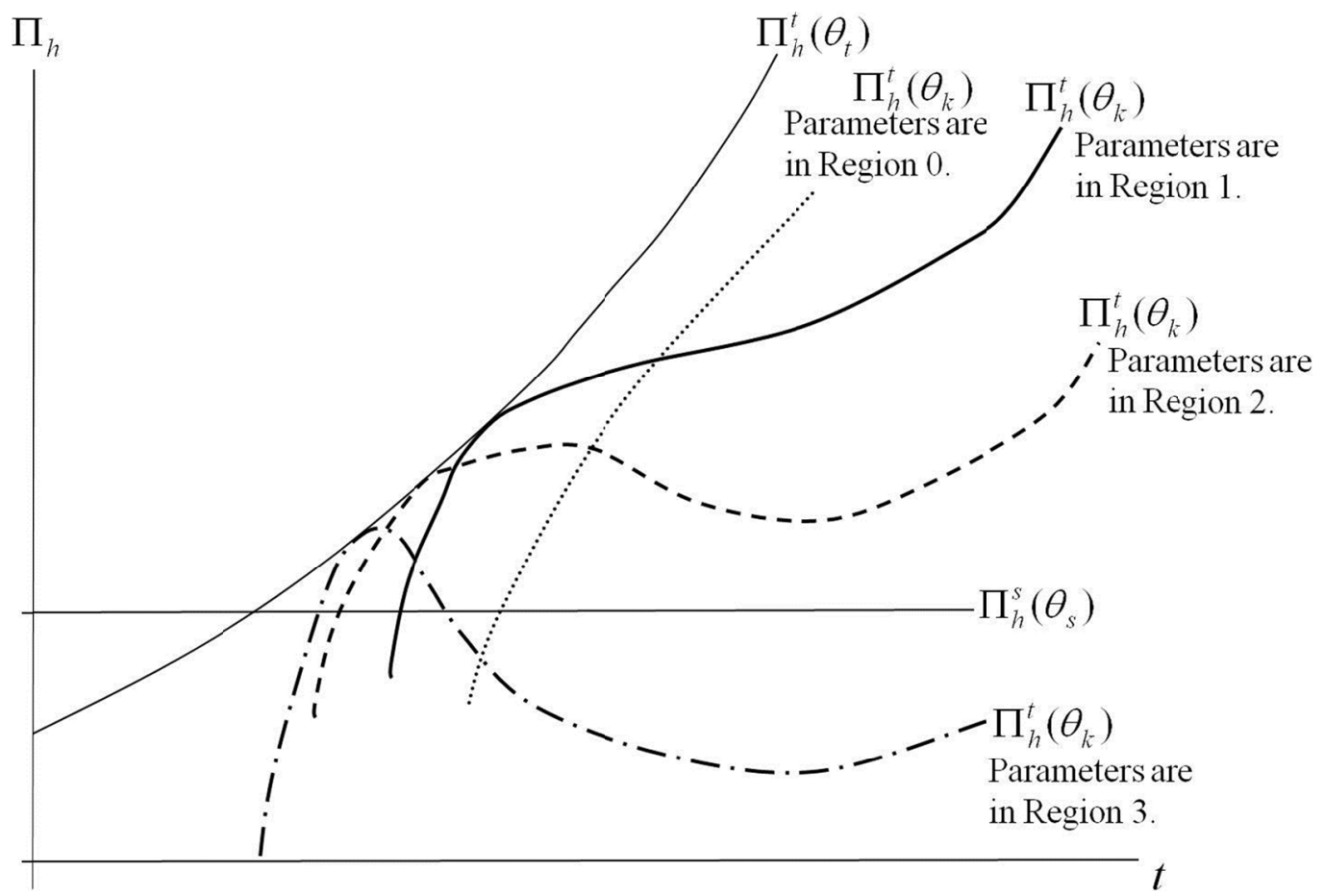

Figure 2. The shapes of the expected profit of the home firm 


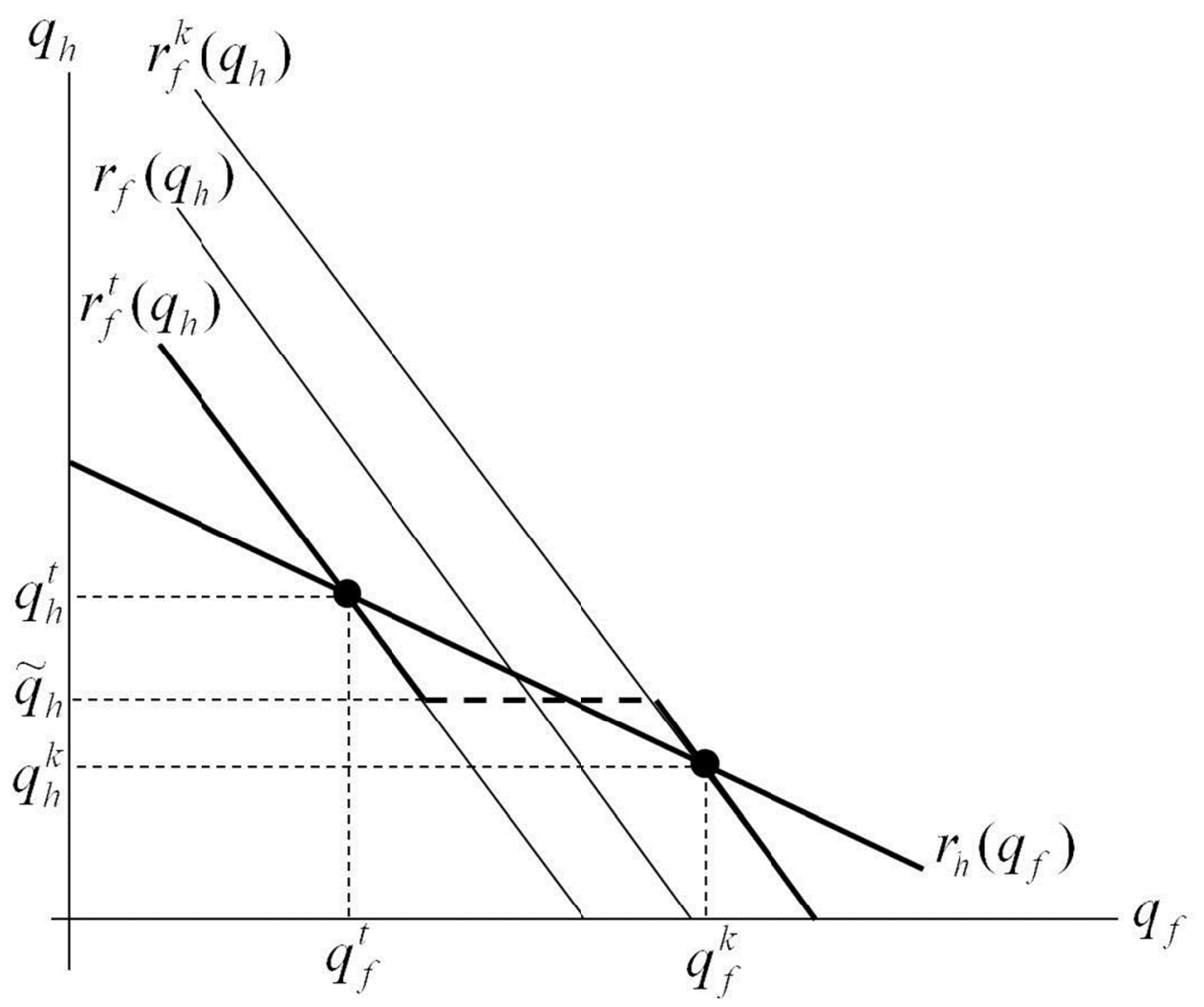

Figure 3. Equilibrium in stage 0 